\title{
THE READING OF SCRIPTURE IN THE GATHERING OF THE EARLY CHURCH
}

\section{INTRODUCTION}

The phenomenon of public reading of Scripture in the context of the gathering of early Christian communities has repeatedly received the scholarly attention of both historians of the early Church and liturgiologists. However, most studies on the subject seem to depart from questionable historical premises and, as a consequence, lead to unconvincing results. Therefore, this chapter will reconsider the history of public reading in the Christian assemblies and, in particular, the origin and development of public reading of Scripture during the first three centuries of the Church's existence. Particular attention will be given to the questions of which genres of writings were read in the communal gatherings and how the role and office of reader originated and developed.

1. The origin of SCRipture ReAding In the CHRISTIAN GATHERING

\section{a. Public reading at the Graeco-Roman banquet}

Before exploring the issue of the origin of Scripture reading in the early Christian gathering it may be helpful to review how public reading functioned in late antiquity in general. The normal way to read a text was to read it out loud, whether before an audience, in the company of friends or alone. However, silent reading was not unknown, and there is ample evidence for such practice in antiquity. ${ }^{1}$ Reading aloud was part of ancient education and it was regarded as the only recognized means of gaining the full meaning of the written page. Reading aloud even to oneself was the usual custom of antiquity as

\footnotetext{
1 B. Knox, "Silent Reading in Antiquity," GRBS 9 (1968), 421-435.
} 
is illustrated by the example from Acts 8:30 where Philip hears the Ethiopian eunuch reading from the prophet Isaiah. ${ }^{2}$ Vocalized reading also occurred at public presentations of literary compositions. Authors gave public performances of their works with some regularity, and one of the characteristics of public games was a poet reading aloud from his writings. Reading aloud written texts also became typical of early Christian gatherings from the middle of the first century onwards. ${ }^{3}$

In Graeco-Roman antiquity, texts were generally written with the intention of being reproduced as oral presentations. Gamble observes that:

Christianity's orientation to texts was, moreover, something that stood out in the eyes of its ancient critics. When in the middle of the second century Lucian of Samosata satirized the figure of Peregrinus (De morte Peregrini 11), what especially caught his attention about Christianity was its penchant for writing and interpreting books. ${ }^{4}$

Audible reading was also necessary because in antiquity, texts were written in scriptio continua: there was little or no division between words, sentences, or paragraphs, and little or no punctuation. Therefore, the reader was obliged to constitute the sense of a text by vocalizing it, and in this manner, the reader converted the written into the oral. $^{5}$

Public reading could be performed, as in modern times, in different life contexts. Dio Chrysostom describes how, walking through the hippodrome, he encountered people playing the flute, dancing, performing tricks, reading out a poem, singing, and recounting a history or tale. ${ }^{6} \mathrm{~A}$ very common context, however, was the after-dinner symposium. $^{7}$

At the symposium various types of texts could be read: philosophy, scientific treatises, history, poetry, and comedy. According to Aulus Gellius, at a banquet of the philosopher Taurus the Symposium of

2 G. Hendrickson, “Ancient Reading,” CJ 15 (1929-1930), 186-193.

${ }^{3}$ P. Achtemeier, "Omne Verbum Sonat: The New Testament and the Oral Environment of Late Western Antiquity," JBL 109 (1990), 16.

${ }^{4}$ H. Gamble, "Literacy, Liturgy, and the Shaping of the New Testament Canon," in The Contribution of the Chester Beatty Gospel Codex P45, ed. Charles Horton (London and New York: T \& T Clark, Continuum, 2004), 27-39, esp. 29.

${ }^{5}$ H. Gamble, Books and Readers in the Early Church: A History of Early Christian Texts (New Haven and London: Yale University Press, 1995), 204.

${ }^{6}$ Dio Chrys. 20.10.

${ }^{7}$ Plut., Quaest. conv. 7.711b-712c; Plin., Ep. 1.15.2. 
Plato was read. ${ }^{8}$ At the dinner of the philosopher Favorinus "there was usually read either an old song of the lyric poets, or something from history, now in Greek and now in Latin." Gellius once heard the reading of a passage from the treatise of Gavius Bassus On the Origin of Verbs and Substantives. ${ }^{10}$ Plutarch notices that, as entertainment at a banquet, the dialogues of Plato could be recited and even performed. ${ }^{11}$ According to Lucian, the blessed ones who live on the Isle of the Blest enjoy a symposium accompanied by poetry and songs. Here, mostly the poems of Homer are read or recited. ${ }^{12}$ In Lucian's Symposion, the grammarian Histiaios recited a combination of verses of Pindar, Hesiod and Anacreon. ${ }^{13}$ Plutarch states that the comedian Menander is particularly fit to be read at symposia. ${ }^{14}$

The reading at symposia could be performed by persons of various statuses. First, the person who read the literary text could be the author of the text himself, who by reading his composition hoped to elicit the comments and reactions of the participants in the banquet. ${ }^{15}$ Petronius relates that Trimalchio at his banquet read his last will and also some poetry of his own making as well as a long passage from Publilius Syrus, the composer of mimes. ${ }^{16}$ Second, the reading could be performed by the host of the banquet. Third, the task of reading

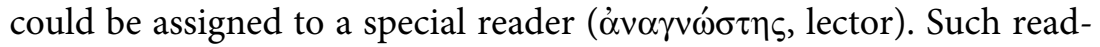
ers would often be educated slaves, whose duty in Roman houses was to entertain their master and his guests at table by a recitation in Greek and/or Latin. ${ }^{17}$ Atticus, for instance, had very good readers, whom he thought indispensable at dinner parties. ${ }^{18}$ Gellius relates that a slave usually stood by the table at dinner with the philosopher Favorinus. ${ }^{19}$ Plutarch states that slaves could be charged with the recitation and

8 Aul. Gel., NA 17.20.

9 Aul. Gel., NA 2.22.

10 Aul. Gel., NA 3.19.

${ }^{11}$ Plut., Quaest. conv. 7.711c.

${ }^{12}$ Luc., Ver. hist. 2.15.

${ }^{13}$ Luc., Symp. 17.

${ }^{14}$ Plut., Quaest. conv. 7.712b.

15 E.J. Kenney "Books and Readers in the Roman World," in The Cambridge History of Classical Literature, Volume II, Latin Literature, eds. E.J. Kenney and W.V. Clausen (Cambridge: Cambridge University Press, 1982), 11; Raymond Starr, "The Circulation of Literary Texts in the Roman World," CQ 37 (1987), 213.

${ }_{16}$ Petr., Satyr. 71.4; 55.

${ }^{17}$ See J.W. Duff and A.J.S. Spawforth, "anagnostes," in $O C D$, p. 80.

${ }_{18}$ Nep., Att. 13.3; 14.1.

19 Aul. Gel., NA 3.19. 
performance of Plato's dialogues. ${ }^{20}$ These data may suffice to warrant the conclusion that reading of literary compositions was a well-known practice at the Graeco-Roman banquet.

\section{b. Reading of Scripture in Jewish communal gatherings}

For the purpose of the present research it is important to look at the background of the reading of Scripture by first-century CE Jews in their synagogues and by Jewish groups as, for instance, those whose practices are reflected in the Qumran scrolls and the Therapeutae. Pierre Grelot points out that the available references to Jewish liturgical reading of Scriptures in the synagogue come from a relatively late time. Even then descriptions of Sabbath assemblies give no clear and detailed picture. Scripture readings in Palestinian and Babylonian communities were not fixed. But it is clear that essential elements which formed part of the synagogue liturgy according to rabbinic sources, such as the reading of Scripture, existed already in the synagogue in the time of Jesus and the apostles. ${ }^{21}$ The Jewish synagogue was used for many communal activities; however, as Josephus asserts, it was in the first place a center of study for the entire community. ${ }^{22}$ Philo speaks in the same vein: "He [Augustus] knew therefore that they have houses of prayer and meet together in them, particularly on the sacred Sabbaths when they receive as a body a training in their ancestral philosophy." 23

Several sources, among them Philo, Josephus, the inscription of Theodotus and the book of Acts, show that in the first century CE the reading of the Torah constituted the primary and almost exclusive function of the religious activity in the synagogue. ${ }^{24}$ In an account of Jews gathering in the synagogue Philo says: "And will you sit in your conventicles and assemble your regular company and read in security your holy books, expounding any obscure point and in leisurely comfort discussing at length your ancestral philosophy?"25 According to

\footnotetext{
20 Plut., Quaest. conv. 7.711c.

21 Pierre Grelot, La liturgie dans le Nouveau Testament (Paris: Desclée, 1991), $32-33$.

22 Jos., Ant. 16.2.4; Mk. 1:21; 6:2.

23 Philo, Legat. 156 (tra. F.H. Colson).

24 Lee Levine, “The Second Temple Synagogue: The Formative Years," in The Synagogue in Late Antiquity, ed. Lee Levine (Philadelphia: Asor, 1987), 14-15.

25 Philo, Som. 2.127 (tra. G.H. Whitaker and F.H. Colson).
} 
Philo, at least two people participated in the reading and interpretation of the Scriptures in the Alexandrian synagogues:

For that day has been set apart to be kept holy and on it they abstain from all other work and proceed to sacred spots which they call synagogues. There, arranged in rows according to their ages, the younger below the elder, they sit decorously as befits the occasion with attentive ears. Then one takes the books and reads aloud and another of special proficiency comes forward and expounds what is not understood. ${ }^{26}$

In the surviving excerpts of his Hypothetica, Philo says that Jews gather on the Sabbath in certain habitual places for the reading of the Law:

And indeed they do always assemble and sit together, most of them in silence except when it is the practice to add something to signify approval of what is read. But some priest who is present or one of the elders reads holy laws to them and expounds them point by point till about the late afternoon. ${ }^{27}$

Josephus also says:

[Moses] appointed the Law to be the most excellent and necessary form of instruction, ordaining, not that it should be heard once for all or twice or on several occasions, but that every week men should desert their other occupations and assemble to listen to the Law and to obtain a thorough and accurate knowledge of it, a practice which all other legislators seem to have neglected. ${ }^{28}$

This literary evidence from Philo and Josephus is confirmed by the Jewish inscription of Theodotus (Jerusalem, before $70 \mathrm{CE}$ ) which tells us that the synagogue he built was meant for the reading of the Law and instruction about it. This is how the inscription reads: "Theodotus, son of Vettenus, priest and archisynagogos, son of an archisynagogos, grandson of an archisynagogos, constructed the synagogue for the reading of the Law and the teaching of the commandments...."29

In his remarks about what happened in the Jewish synagogues on the Sabbath, Luke, too, intimates that the reading of the Law was a weekly practice. He has James say: "For in every city, for generations

\footnotetext{
${ }^{26}$ Philo, Quod omn. prob. 81-82 (tra. F.H. Colson).

${ }_{27}$ Philo, Hyp. in Euseb., Praep. ev. 8.7.12-13 (tra. F.H. Colson).

${ }^{28}$ Jos., Ap. 2.175 (tra. H.St.J. Thackeray). Cf. Jos., Ant. 16.44.

${ }^{29}$ Charles Perrot, "The Reading of the Bible in the Ancient Synagogue," in Mikra. Text, Translation, Reading, and Interpretation of the Hebrew Bible in Ancient Judaism and Early Christianity, ed. M.J. Mulder (Assen: Van Gorcum; Philadelphia: Fortress, 1988), 137.
} 
past, Moses has had those who proclaim him, for he has been read aloud every Sabbath in the synagogues." ${ }^{30}$

All in all, the evidence available from the first century CE seems to justify the conclusion that, in that century, the synagogue was the place for reading and studying the Jewish sacred books, in contrast to the Temple cult, which mainly consisted of sacrificial rites.

Later, at the end of the second or beginning of the third century $\mathrm{CE}$, the service of the synagogue consisted of the Shema', prayer, the reading of the Law and the Prophets, and the Blessing. ${ }^{31}$ The reading from the Law followed a triennial cycle that completed the Pentateuch once every three years, a system believed by some to go back to the first century BCE. ${ }^{32}$ However, in the first century, at least until $70 \mathrm{CE}$, there is no reference to the synagogal reading of the Prophets in Jewish sources. ${ }^{33}$ The story about Jesus reading Isaiah $61: 1-2$ in Luke 4:16-17 cannot be used as evidence to the contrary, since the story is clearly composed by Luke to have Jesus himself prove his messiahship on the basis of an Old Testament prophecy. ${ }^{34}$ In the account of Paul visiting Antioch in Pisidia, there is a reference to a reading of the Prophets (Acts 13:15), but the expression "of the Prophets" here seems to be due to Luke's use of the standard phrase "the Law (or Moses) and the Prophets." ${ }^{\prime 35}$ At the same time, Luke 4:16-17 and Acts 13:15 reflect the situation of Christian communities at the end of the first century,

30 Acts 15:21.

31 Mishnah, Meg. 4.3.

32 H.H. Rowley, Worship in Ancient Israel. Its Forms and Meaning (London: SPCK, 1967), 234-235.

${ }^{33}$ In this context it may be significant that the works of Philo of Alexandria include a considerable number of commentaries on the books of Moses but not a single commentary on any of the Prophets. Naomi G. Cohen, Philo's Scriptures: Citations from the Prophets and Writings (Leiden: Brill, 2007), argues that Philo's citations from the Prophets and writings indicate that a Haftarah Cycle was already on the way to become customary in Alexandria in the first century CE. However, the evidence discussed by Cohen does not justify her conclusion. An early indication of the reading of "Prophets" in the synagogue in the first century is 2 Bar. 86.1-2.

${ }^{34}$ The episode Lk. 4:17-21 (the reading from Isaiah) does not rest on tradition from Mark or Q. It has been created by Luke as an expansion of Mk. 6:1-2 and inserted in Mk. 6:2. Moreover, the "quotation" from Isaiah is not a coherent biblical passage but a combination of Isaiah 61:1-2 and 58:6, which forms a text which could hardly have chosen as Scripture reading, "gewiss in keiner Prophetenrolle zu finden," H. Schürmann, Das Lukasevangelium, vol. 1 (Freiburg, Basel, Wien: Herder, 1969), 229.

${ }^{35}$ Cf. Lk. 16:16, 29; 24:27, 44; Acts 13:15; 24:14; 28:23. 
when in their gatherings Christians read the Prophets to sustain their Christological claims about Jesus. ${ }^{36}$

Judging from the writings found at Qumran it was considered important that the public reading of Scripture was performed with great care. A neglectful reading of the Law was regarded as a serious offence. Indistinct reading without sufficient articulation had to be avoided: "And anyone who speaks weakly or staccato, without separating his words to make his voice heard, such men should not read in the book of the Torah, so that he will not lead to error in a capital matter" (4Q266 5.2). A "blasphemous" slip committed in the act of reading or in the saying of prayers, could result in permanent expulsion from the community: "whether blaspheming, or suddenly overtaken by misfortune or for any other reason, $\{\ldots\}$ or reading a book, or blessing, will be excluded and shall not go back ever to the Community council" (1QS 7.1). Of course, these remarks refer to the reading of the Torah, and one should be cautious in making assumptions about the reading of other writings, such as pesher commentaries, in the community concerned. ${ }^{37}$ The author of the Community Rule outlines procedures for a group meeting immediately following the reference to the Torah watch: "And the Many shall be on watch together for a third of each night of the year in order to read the book, explain the regulation, and bless together" (1QS 6.7-8). "The book" (4Q397 14-21) is likely to refer here to the Torah; reading it probably means reading aloud to those assembled. The Rule of the Congregation also alludes to a largegroup gathering. Interestingly, it assumes that women and children will be present when the Law is read and interpreted in the last days: "When they come, they shall assemble all those who come, including children and women, and they shall read into their ears all the precepts of the covenant, and shall instruct them in all their regulations, so that they do not stray in their errors" (1QSa 1.4-5). Just like those who attended the meetings on Sabbath in the synagogues, those who used the Qumran texts devoted themselves to the reading and studying of the Law in their gatherings.

${ }^{36}$ The evidence for the reading of Prophets in early Christian gatherings (from 1 Tim. 4:13 onwards) will be discussed in section 2a below.

${ }_{37}$ Gregory Snyder, Teachers and Texts in the Ancient World (London and New York: Routledge, 2000), 146. 
Led by the evidence concerning the reading of the Law by Jews, generations of scholars agree that the origin of Scripture reading in the Christian communities can be found in the Jewish synagogue. In this traditional and still current view, it has been taken for granted that the reading of Scripture in Christian assemblies has its origins in the reading of the Law in the synagogue if only for the fact that it was the Jewish Scriptures that were read in the Christian gatherings. ${ }^{38}$ The earliest Christians, who were Jews, had passed on the custom of meeting weekly to read and interpret the Law and the Prophets as well as the practice of singing psalms and saying prayers and thanksgivings. Jews had a veneration of their scrolls that was enhanced by ritualized reading in a religious context. In time, reverence for the Word of God and the use of sacred books in religious gatherings became characteristic of Christians as well. ${ }^{39}$ It has sometimes been added as an argument for tracing back the reading of Scripture among Christians to the synagogue, that there are no clear-cut or convincing parallels for it in other religions except Judaism, apart from religions that have been influenced by Christianity. Thus, on the assumption that there was historical continuity between Jewish and Christian cultic practices, Gerard Rouwhorst, for instance, infers that the reading of Scripture in Christian gatherings has its roots in Judaism or has been influenced by Judaism in one way or another. ${ }^{40}$

Some scholars defend the same view on still another ground. They argue that education in religious communities was largely based on the reading of texts. Education in the ancient world in general was to a large extent based upon the reading of literature. In reading and explaining the Scriptures, the synagogue functioned as a school. So did Christian communities, which continued to read and explain the Scriptures in their gatherings. According to this view, Christians took this over as an educational practice; the reading of Scriptures in Chris-

${ }^{38}$ Frances Young, "Christian Teaching," in Cambridge History of Early Christian Literature, eds. F. Young, L. Ayres, and A. Louth (Cambridge: Cambridge University Press, 2004), 91.

${ }^{39} \mathrm{Ib} ., 92$.

${ }^{40}$ G. Rouwhorst, "The Reading of Scripture in Early Christian Liturgy," in What Athens has to do with Jerusalem. Essays on Classical, Jewish, and Early Christian Art and Archaeology in Honor of Gideon Foerster, ed. Leonard Rutgers (Leuven: Peeters, 2002), 305. 
tian gatherings is considered to have had its origins in the reading of Scripture in the synagogue. ${ }^{41}$

However, the view that the reading of texts in Christian communities derives from the practice of reading and studying the Law in Jewish communities does not seem to be confirmed by the data contained in early Christian literature. To decide about the origin of reading the Scripture in the gatherings of Christians it is necessary to look at the data more precisely.

\section{c. Public reading in Christian communities}

Clear evidence concerning the reading of authoritative texts during the Christian Sunday gathering first emerges in Justin's First Apology:

And on the day called Sunday, all who live in cities or in the country gather together to one place, and the memoirs of the apostles or the writings of the prophets are read, as long as time permits; then, when the reader has ceased, the president verbally instructs, and exhorts to the imitation of these good things. ${ }^{42}$

In the same work Justin refers once again to "the memoirs of the apostles" and calls them "gospels." ${ }^{33}$ It may be inferred from the way in which Justin mentions the reading of texts here as something customary that in his time the reading of the Gospels or the Prophets took place because it was already, to a certain extent, an established tradition and not because there were practical reasons to read a particular chosen passage. However, there was no set format for the readings: it could be the Gospels or the Prophets, or perhaps both. The Prophets read in Justin's congregation might well have been the Old Testament Prophets. Canon Muratori (Rome, about $180 \mathrm{CE}$ ) ${ }^{44}$ says that the Pastor of Hermas must not be read in the Church, "neque inter prophetas, completo numero, neque inter apostolos." 45 That is: neither among the Prophets, because their number has been completed (i.e., their canon

${ }^{41}$ F. Young, "Christian Teaching," 469.

42 Just., 1 Apol. 67.3.

${ }^{43}$ Just., 1 Apol. 66.3.

${ }^{44}$ For the date of Canon Muratori, much debated in recent scholarly literature, see J. Verheyden, "The Canon Muratori. A Matter of Dispute," in The Biblical Canons, eds. J.-M. Auwers and H.J. de Jonge, (Leuven: University Press \& Peeters, 2003), 487-556.

${ }^{45}$ Canon Muratori, line 4. 
has been fixed), nor among the Apostles. From the phrase "their number has been completed" it is clear that Canon Muratori is referring to the Prophets of the Old Testament. When Justin says that in the Christian gathering the Prophets were read, he is likely to refer, therefore, to the Old Testament Prophets.

By the end of the second century, Tertullian offers a description of the weekly Christian gathering in the evening. ${ }^{46}$ Speaking about the Scripture reading in the meeting of Christians he says:

We meet to read the books of God-if anything in the nature of the times bids us look to the future or open our eyes to facts. In any case, with those holy word we feed our faith, we lift up our hope, we confirm our confidence; and no less we reinforce our teaching by inculcation of God's precepts. ${ }^{47}$

In another passage Tertullian specifies that in churches the authentic writings of the apostles are read. Elsewhere he also mentions the Scripture reading in the context of a Christian assembly on the Lord's day. ${ }^{48}$

The above evidence shows that the reading of Scripture-that is, of Israelite and Jewish writings that the second-century Church would begin to call the Old Testament, and of new compositions that would later belong to the New Testament-was a regular feature of the meetings of Christians in the second century CE. About $100 \mathrm{CE}$ the author of 1 Timothy admonishes his addressee to devote himself to the public reading of Scripture. ${ }^{49}$ Since there is no evidence that there existed special meetings intended only for the reading of Scripture and preaching, it is probable that portions of the Old Testament in Greek were read in the context of the Sunday gatherings consisting of the supper and the after-supper session. As there is no indication until the third century

46 That Tertullian in Apol. 39. is referring to an evening meal is clear from his terminology: cenulae nostrae (39.14); cena nostra (39.16); convivium (39.17 and 18); per noctem (39.18); lumina (39.18); it is also clear from the fact that participants in the meal are said to invite other participants to sing a song to see if the latter are not drunk (39.18). That Tertullian is speaking here about the Eucharist can be inferred from the fact that he compares the Christians' meal with the sacramental meals of the Dionysian and Attic mysteries and the cultic banquets in honour of Serapis.

${ }^{47}$ Tert., Apol. 39.3.

48 Tert., Praescr. 36; An. 9.

491 Tim. 4:13. 
that Christians in their gatherings read the Law of Moses, ${ }^{50}$ it is most probable that in their gatherings early Christians read other books of the Old Testament, for example, the Prophets.

As far as the reading of Christian texts is concerned, apostolic letters have probably been read in Sunday gatherings of Christians since the middle of the first century. This can be inferred from 1 Thessalonians 5:27, Acts 15:31, Colossians 4:16, Revelation 1:3 and 22:18, and possibly 2 Peter 3:14-16. In the beginning, the reading of apostolic letters was not a liturgical practice. Rather these letters were read just as letters received. A letter brought by a messenger could be read by him to the addressee if he were able to do so. ${ }^{51}$ It is evident from many early Christian letters which have been preserved that they had to be heard by all members of a Christian community, the only possibility for this being in their communal gathering.

However, as has been stated before, Justin mentions the reading, not of letters, but of the Gospels and the Prophets in the assemblies of Christians on Sunday. This raises the question as to why Christians began to read literature in their community gatherings at all. This question will be treated in the following section.

To summarize the present section, the reading of literary compositions in Christian assemblies is likely to have followed the existing model of reading literature in first-century Graeco-Roman culture at large. As has been shown above, the early Christians met in private houses on Sunday evening and held their symposia in a way similar to the way other, non-Christian, groups did in those days. Accordingly, they practised public reading at their symposia and they, too, had special readers to do the reading, at least from some point of time in the second century onwards..$^{52}$ The reading of authoritative writings took place in the social session connected with the supper. That was

${ }^{50}$ Or., Hom. Jos. 4.1; Hom. Gen. 12.1. According to Melito of Sardes, On Pascha, he read Exodus 12 at Easter, but this is of course a special case; it is not the reading in a regular Sunday gathering.

51 There is an interesting parallel to this in Lucian's Symposion 21 that speaks about a certain Stoic, Hetoemocles, who sent his slave to the symposium of his friends with a tablet that contained some of his writing. The slave said that his master had ordered him to read it so that all participants of the banquet could hear it. Than he approached the lamp and read the message after receiving the permission of Aristaenetus, the host.

${ }_{52}$ Tert., Praescr. 41.8. 
the context in which apostolic and other important letters, ${ }^{53}$ Prophets and Gospels were read aloud to the community gathered for its weekly supper and conviviality. There is a close analogy between the reading of texts during non-Christian banquets and that during the Christians' gatherings connected with their weekly supper. This analogy cannot be incidental. We are witnessing here the same phenomenon in nonChristian and Christian contexts. The analogy challenges the current view, recently upheld by Wayne Meeks and Frances Young, according to which the reading of the Scriptures in the gatherings of Christians should be traced back to the Jewish practice of reading and studying the Law of Moses on Sabbath in the synagogue. ${ }^{54}$ More importantly, the reading of the Law on Sabbath in the synagogue did not take place in the context of a meal, as was the case with the reading of texts in Christian gatherings. ${ }^{55}$ Moreover, as was mentioned above, what was read in the weekly gatherings of the Christians was not the Law, whereas what was read and studied in the first-century synagogue was exclusively the Law. There is no continuity between the reading in the synagogue and that in the Church. Therefore it cannot be correct to trace the public reading of Scripture in Christian communities back to a practice of the Jewish synagogue.

\section{Development of the public Reading of Scripture in the Christian COMMUNities}

\section{a. Public reading of Scripture in the early Church in the first century}

Christians began to read apostolic epistles in their gatherings at the latest from the middle of the first century onwards. This can be inferred from 1 Thessalonians 5:27. Probably the earliest information about the actual reading of such a letter is found in Acts 15:22-35. According to

531 Clem. 47.1-3 invites the Corinthian Christians to read Paul's first letter to the Corinthian church. The author must mean that the letter should be read aloud in the community. Similarly, his own letter, 1 Clement, was possibly read aloud in the gathering of Corinthian Christians by the messengers from Rome, Claudius Ephebus, Valerius Bito and Fortunatus, mentioned in 65.1.

${ }^{54}$ F. Young, "Christian Teaching," 91-104; Wayne Meeks, "Social and Ecclesial Life of the Earliest Christians," in The Cambridge History of Christianity, vol. 1, Origins to Constantine, eds. Frances M. Young and Margaret M. Mitchell (Cambridge: Cambridge University Press, 2006), 167.

${ }_{55}$ See, e.g., Just., 1 Apol. 67; Tert., Apol. 39. 
this passage, the apostles and elders of the Jerusalem church sent Judas, Silas, Paul, and Barnabas to Antioch with the letter that contained the decision of the Jerusalem council. On their arrival in Antioch they gathered the whole community ( $\tau$ ò $\pi \lambda \hat{\eta} \theta 0 \varsigma$ ) and delivered the letter. Luke remarks that the people rejoiced at the exhortation, thus making it clear that he means that the letter was read aloud. Moreover, the address on the letter (Acts 15:23) shows that Luke meant it to be a circular letter, addressed to Christian communities in various regions. Obviously, Luke was acquainted with the phenomenon of letters being copied and circulated by messengers to several places, where they had to be read aloud to the local audiences. ${ }^{56}$

At the end of the second century, Clement of Alexandria speaks of this letter mentioned in Acts 15:30 as "the Catholic epistle of all the Apostles" that was "conveyed to all the faithful by the hands of Paul himself" and was later incorporated into the book of Acts. ${ }^{57}$ It seems that when Luke was writing Acts he knew about the existing practice of Paul and probably other apostles sending letters to be read in the churches they wanted to instruct or encourage. The letter read to the assembly in Antioch represented the voice of the apostles and Judas and Silas were sent along as the confirmation of their voice and message. The author of Colossians (about $80 \mathrm{CE}$ ) presupposes the same practice when he represents Paul sending his fellow workers along with his letter..$^{58}$

Reminiscences of readings in Christian meetings occur repeatedly in Paul's writings. 1 Thessalonians 5:27 already presupposes the reading of this letter in the gathering of the Christian congregation at Thessalonica, probably in the gathering following the weekly supper. Paul solemnly charges the Christians in the Thessalonian church to read his epistle "to all the brothers." The instructions he gives in the letter are of important relevance to all members of the church and that is why he uses the strong word غंvоркí $\omega$ (which means "to place someone under a solemn charge") to emphasize that his letter should be read to the whole congregation.

\footnotetext{
${ }^{56}$ Craig Keener, The IVP Bible Background Commentary: New Testament (Downers Grove: InterVarsity Press, 1993), 366.

${ }^{57}$ Clem. Al., Str. 4.15.

${ }^{58}$ Col. 4:7-8.
} 
Even a seemingly private letter as that of Paul to Philemon was likely intended to be read in the gathering of a Christian congregation, namely, in the church that met in Philemon's house. The letter is addressed "to Philemon our dear friend and fellow worker, to Apphia our sister, to Archippus our fellow soldier and to the church that meets in your home." 59 This seems to indicate that this personal letter was intended to be read to the whole congregation.

The main reason why Paul wanted his letters to be read publicly was the low literacy level among the members of any congregation. Most of them were unable to read. The best way to be informed of the content of Paul's message was to have it read during the church's meeting. Another reason was that the apostle could not be present continuously in all of the churches he wanted to instruct. ${ }^{60}$ In antiquity, however, letters were often regarded as a replacement for oral communication and fulfilling the functions of oral speech. ${ }^{61}$ Since letters could take the place of the sender and his message, the reading of the apostle's letter could compensate for the absence of the apostle. ${ }^{62}$

An indication showing that the reading of Paul's letters in Christian congregations had become something usual may be found in Ephesians 3:4. Here, the author says: "Reading this, then, you will be able to perceive my understanding of the mystery of Christ." Since the author is addressing here a whole congregation, the reading mentioned was probably something that took place in the congregation's gathering. It seems that with time the practice of reading Paul's letters in church meetings had established itself.

Besides the epistles written to a specific church there are letters addressed to a number of churches. A case in point is Paul's letter to the Galatians. ${ }^{63}$ Precisely which churches Paul is addressing here is a much-debated question which can be left aside here. In any case it is clear that Paul is writing to several churches founded by him. In these churches problems had arisen and he seeks to solve these with this letter. Meeks rightly points out that the plural in the address of the letter to the Galatians makes it plain that several communities are

\footnotetext{
${ }_{59}$ Phlm. 1-2.

${ }^{60}$ Moody Smith, "When did the Gospels Become Scripture?" JBL 119 (2000), 5.

${ }^{61}$ David Aune, The New Testament and Its Literary Environment (Philadelphia: The Westminster Press, 1987), 158.

${ }_{62}$ Klaus Traede, Grundzüge griechisch-römischer Brieftopik (München: Beck, 1970), 95-106.

${ }^{63}$ Gal. 1:2.
} 
expected to hear it read to them, probably in successive meetings as Paul's messenger took it from one place to the next. Possibly in some cities the letter was read in individual households rather than to "the whole assembly" gathered at one single place like Gaius' house in Corinth. ${ }^{64}$

Another instance of a letter being read in more than one congregation is 2 Corinthians. Paul addresses this letter to the church in Corinth with "all the saints throughout the whole of Achaia." ${ }^{65}$ This address seems to imply that Paul supposed his letter to be read not only in a gathering of the Corinthian church, but also in gatherings of other churches in Achaia.

A further example of a letter intended to be read in more than one church is Colossians. Colossians 4:16 states: "When this letter has been read among you, have it read also in the church of the Laodiceans; and see that you read also the letter from Laodicea." From this passage it is clear that Paul's letters, at least according to the author to the Colossians, were read more widely than in the communities to which Paul had sent them originally. Obviously, Paul's letters were read in various churches because he was considered to be a prominent apostle by them, not because he addressed a letter to them. In light of the pseudepigraphical character of the epistle to the Colossians, one cannot even be sure that it was meant to be read specifically in Colossae and Laodicea. The author may well have intended it to be read to a wider circle of churches in Asia.

The letter to the Ephesians, too, has the character of a circular letter. Its purpose is to convey to a number of churches in the province of Asia the idea of the unity of the Church composed of Jews and nonJews. From some important textual witnesses (Papyrus 46, the first hand of Sinaiticus and Vaticanus and some minuscules) "in Ephesus" in Ephesians 1:1 is absent. If "in Ephesus" was indeed not part of the original text, this might indicate that this letter "was intended as an encyclical, copies being sent to various churches." ${ }^{\prime 66}$ Other letters from other writers, such as James and 1 Peter, also have the character of a

${ }^{64}$ Wayne Meeks, The First Urban Christians (New Haven and London: Yale University Press, 1983), 143.

652 Cor. 1:1.

${ }^{66}$ Bruce M. Metzger, A Textual Commentary on the Greek New Testament, 2nd ed. (Stuttgart: United Bible Societies, 1994), 532. 
circular letter and most likely were composed to be read publicly in several churches.

Paul's letters were naturally first read in the gathering of the churches to which they were addressed. Later on, such churches proceeded to read the same letter again and even to repeat the reading of that letter regularly. There is a somewhat late testimony attesting to this in Tertullian who says that letters of Paul and other apostles are still being read in the churches to which they had been sent. ${ }^{67}$ The development is also reflected in the letter of Dionysius of Corinth to the church of Rome (ca. 170) in which Dionysius says that on Sunday the Corinthian church regularly read Clement's letter to the Corinthians. ${ }^{68}$

It was a most important development in the history of the gathering of the Christian Church that, during the first century $\mathrm{CE}$, in some Christian congregations, certain apostolic writings came to be read not only once, on their receipt, but repeatedly, for the edification of the hearers. This innovation is reflected in a passage in 1 Timothy in which the author admonishes his addressee to devote his attention to the public reading of the Scriptures. He writes: "Until I arrive, give attention to the public reading of scripture, to exhorting, to teaching." ${ }^{69}$ For "the public reading of scripture", the Greek has simply $\tau \hat{\eta}$ $\dot{\alpha} v \alpha \gamma v \omega ́ \sigma \varepsilon 1$, but from the context ${ }^{70}$ it is clear that the author is referring here to the practice of reading authoritative texts in the community gathering. The author means that the "reading", "exhorting" and "teaching" took place in the same gathering of the congregation, and that the exhortation and teaching were based on what had been read. Certain texts were now read more than once, as a basis for exhortation and teaching. Half a century later, the custom of reading authoritative writings and using the passages read as a starting point for admonitions and exhortations, is clearly attested in Justin. ${ }^{71}$ However, judging from 1 Timothy, in Ephesus, for instance, this custom had established

${ }^{67}$ Tert., Praescr. 36.1-2: "percurre ecclesias apostolicas apud quas ipsae adhuc cathedrae apostolorum suis locis praesident, apud quas ipsae authenticae litterae eorum recitantur sonantes uocem et repraesentantes faciem uniuscuiusque. Proxima est tibi Achaia, habes Corinthum. Si non longe es a Macedonia, habes Philippos; si potes in Asiam tendere, habes Ephesum; si autem Italiae adiaces, habes Romam unde nobis quoque auctoritas praesto est."

${ }^{68}$ Euseb., HE 4.23.11.

691 Tim. 4:13.

${ }^{70} 1$ Tim. 4:11-16; see, e.g., v. 11: "Pass on these orders and these teachings" and v. 16: "by doing so you will further the salvation of yourself and your hearers."

${ }^{71}$ Just., 1 Apol. 67.3 . 
itself as early as the end of the first century. ${ }^{72}$ The author of 1 Timothy expects the leaders of a Christian congregation to regularly read certain authoritative texts in the gatherings of their congregation. It follows that wherever this custom arose, a certain consensus must have existed as to what texts were fit for regular, repeated reading in the gathering of the community.

The author of 1 Timothy does not say which writings he wanted to be read in Christian congregations, but he may well have been thinking of the letters of Paul and the Old Testament Prophets, as will be argued presently.

First, letters of Paul and letters going under the name of Paul, as we have seen above, were read in gatherings of Christian communities from the middle of the first century at the latest.

Second, the author of 1 Timothy himself was not only acquainted with a number of Paul's letters, ${ }^{73}$ but he also was aware that Paul's letters were read publicly in Christian gatherings. This can be inferred from the form of the Pastoral Epistles themselves, which indicates that the author conceived them as texts to be read aloud in meetings of Christian communities, obviously to imitate the public character of Paul's letters. In fact, although each of the Pastoral Epistles is addressed to one person, all three epistles end with a benediction destined for a plural audience: "Grace be with you" or "with you all", with the personal pronoun in the plural. ${ }^{74}$ The plural suggests that the addressees of the benediction were hearers in a church gathering, at least in the fiction of these letters. If so, the author must have known the custom of reading Paul's letters in such gatherings. In that case, the final words of each of the Pastoral Epistles confirm our suggestion that the reading mentioned in 1 Timothy 4:13 comprised, inter alia, the reading of letters of Paul.

Finally, the tradition of reading apostolic epistles, including those of Paul, in Church gatherings is clearly attested about 180 CE by Canon Muratori. From the way this document speaks about the reading of "apostles" in church it is clear that he is referring to a well-established

\footnotetext{
${ }^{72} 1$ Tim. 1:3 locates Timothy in Ephesus.

${ }^{73}$ See, e.g., how he imitates Paul's letters in the beginning of 1 and 2 Tim. and Tit.

${ }^{74}$ In the Byzantine text of 1 Tim. 6:21; 2 Tim. 4:22 and Tit. 3:15 the plural of the personal pronoun is replaced by the singular form to make it consistent with the rest of the letter.
} 
custom. The apostolic letters which Canon Muratori regards as being read publicly in church gatherings include those of Paul to the Corinthians, Ephesians, Philippians, Colossians, Galatians, Thessalonians, Romans, Philemon, Titus and Timothy as well as the Catholic Epistles of Jude and John. ${ }^{75}$

All in all, then, it may be concluded that the "reading" mentioned in 1 Timothy 4:13 may well apply to the reading of Paul.

Many scholars believe that, in mentioning the reading of certain texts in Church, the author of 1 Timothy was also thinking of the Old Testament Prophets (4:13). ${ }^{76}$ This is probably correct. We know from Justin and Canon Muratori that the Old Testament Prophets were read in church gatherings. ${ }^{77}$ The possibility cannot be ruled out, therefore, that the author of 1 Timothy, too, had the reading of the Old Testament Prophets in mind. They would, of course, be read as confirmation that all that had happened with Jesus and the Church was in accordance with the Scriptures. ${ }^{78}$

It is very improbable, however, that the writings which, according to 1 Timothy 4:13, had to be read in the churches included any Gospels. True, the Gospel of Mark (and Q) already existed, but this work (these works) does (do) not seem to have circulated widely. The other gospels only began to appear at the time. Justin is the first to inform us that, in the gatherings of Christians, Gospels were read. As pointed out above, there is no evidence that in the gatherings of Christians the Law was read prior to the third century. Thus, it seems probable that, according to the author of 1 Timothy, the writings being read were apostolic letters, especially those of Paul, and Old Testament Prophets.

${ }^{75}$ Canon Muratori, lines 50-59: "Hermas...publicare vero in ecclesia populo, neque inter prophetas, completo numero, neque inter apostolos, ... potest."

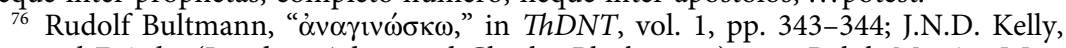
Pastoral Epistles (London: Adam and Charles Black, 1963), 105; Ralph Martin, Worship in the Early Church (Grand Rapids: Eerdmans, 1975), 70; Claude E. Cox, "The Reading of the Personal Letter as the Background for the Reading of the Scriptures in the Early Church," in The Early Church in Its Context, eds. A.J. Malherbe, F.W. Norris, J.W. Thompson (Leiden: Brill, 1998), 74-91, esp. 84-85.

77 Just., 1 Apol. 67; Canon Muratori, lines 79-80.

${ }^{78}$ Cf., e.g., 1 Cor. 15:3; 2 Cor. 3:12-16; Rom. 16:25-27; Mk. 14:27, 49, 61; Lk. 4:1721; 24:25-26; Acts 7:52. Justin Meggitt, "The First Churches: Religious Practice," in The Biblical World, vol. 2, ed. John Barton (London and New York: Routledge, 2002), 164; C.H. Dodd, According to the Scriptures: The Sub-structure of New Testament Theology (London: Nisbet, 1953). 
From 1 Thessalonians 5:27 and Colossians 4:16 it is evident that the reading of apostolic letters was at first not a "liturgical" act, unless in the limited sense that it occurred in the context of the gathering of the Christian community. The texts were not regarded as cultic or liturgical documents, let alone as Scripture, either by their authors or by their addressees. ${ }^{79}$ From the beginning, however, they did have a special status as documents of apostolic authority. As a result, they were read, not only once or twice, but repeatedly, and not only in the churches to which they had been sent, but also in other churches. The recognition of the authoritative character of Paul's letters is reflected, e.g., in 2 Thessalonians 3:14: "If anyone disobeys the instructions given in my letter, single him out, and have nothing to do with him until he is ashamed of himself." By the middle of the second century, the author of 2 Peter puts Paul's letters on a par with "the Scriptures", that is, with the Scriptures of the Old Testament. ${ }^{80}$ Thus, Paul's letters were first read as apostolic messages, then re-read and acknowledged because of their apostolic authority and theological relevance. With time, they were accepted as Scripture by ever growing circles in the Church.

It is precisely the reading of Paul's and other apostolic letters in gatherings of Christian communities that seems to have suggested the possibility of reading the Prophets of the Old Testament as well. Historically speaking, the reading of the Prophets in Christian gatherings can be explained most easily as a phenomenon that arose on the analogy of the reading of apostolic letters. We noticed the first signs of this new phenomenon in 1 Timothy 4:13: "Give attention to the public reading of Scripture," where Scripture is most likely to include the Prophets of Israel, next to the letters of Paul.

An important reason why Christians began to read the Prophets in their gatherings must have been that, as noted above, they felt the Prophets helped them to interpret Jesus' person, work and fate as part of God's plan for Israel and mankind. In the first century, Christians understood Jesus more and more in light of Israel's Prophets. For example, they said that Jesus was raised to life "on the third day, in accordance with the Scriptures," ${ }^{\prime 1}$ probably referring to Hosea 6:2.

\footnotetext{
79 H. Gamble, Books and Readers in the Early Church, 206.

802 Pet. 3:16.

811 Cor. 15:4.
} 
They said that Jesus' death founded a "new covenant," ${ }^{82}$ with an expression borrowed from Jeremiah 31:31. They said that Jesus had been "handed over to death for our trespasses" 83 in words that were reminiscent of Isaiah 53:12. Thus, in reading the Prophets, Christians increasingly discovered who Jesus was and how his ministry had to be understood. In the second half of the first century, then, the reading of the Prophets began to become part of the gathering of the Christian community. ${ }^{84}$ The phenomenon is illustrated by Luke $4: 16-20$, the episode of Jesus in the synagogue in Nazareth. This episode mirrors, if anything, the situation of Luke's own days, in the last decades of the first century CE. In the gathering of a Christian community someone could take a scroll of the prophet Isaiah, read a passage and explain it by saying that this scripture had been fulfilled in Jesus. The reading of the Prophets in gatherings of Christians probably started with the reading of passages that served to sustain and develop early Christian Christology. In the time of Canon Muratori and Justin, reading of the Prophets had become a normal component of the meeting of Christians, at least in Rome.

From the above it may have become clear that in their gatherings first-century Christians began to read apostolic letters and Old Testament Prophets, and their reasons for doing so. There is no explicit evidence that they also read narrative texts such as "gospels" or "acts." Apart from Mark (and Q), which was (were) available about $70 \mathrm{CE}$ at the latest, the Gospels did not originate until the late first century or in the second century. Yet the reading of Gospels in the Church is considered so self-evident in the second century ${ }^{85}$ that the custom may go back to the practice of some communities in the late first century.

If the reading of Gospels in Church gatherings started as early as the last decades of the first century, the question can be asked what prompted the rise of this practice. There can be little doubt that there

821 Cor. 11:25.

${ }^{83}$ Rom. 5:24.

${ }^{84} 1 \mathrm{Tim}$. 4:13. Paul does not yet mention the reading of Old Testament Prophets in gatherings of Christian communities. He does say that in the gathering some people offered instruction ( $\delta 1 \delta \alpha \chi \eta \dot{v} ; 1$ Cor. 14:26). If this was teaching on Jesus' role and significance, it may have implied the reading of passages from Old Testament Prophets; but this remains speculation.

${ }^{85}$ Just., 1 Apol. 67; Canon Muratori, lines 1-9 (on Mt., Mk., Lk. and Jn. with lines 66 and 72 on writings not admitted for public reading); Acta Petri (last decades of the second century, Rome?) 20: "When Peter came into the dining-room he saw that the gospel was being read." 
was a tradition of telling stories about Jesus in gatherings of Christian congregations from his own lifetime onwards. One important reason to tell stories about Jesus was that they supported the ethical teaching transmitted in the Church. As Harm Hollander has argued, the meeting of Christians was an occasion par excellence for telling stories about Jesus in support of moral instruction. ${ }^{86}$ Other scholars have studied the transmission and codification of other synoptic material: aphorisms, sayings on the Kingdom of God, etcetera ${ }^{87}$ Much of the synoptic tradition originated as oral tradition or Church creation (Gemeindebildung) in the Christian community, especially in the Christian gathering. From about the sixties or seventies of the first century $\mathrm{CE}$ onwards, part of the oral tradition was gradually transformed into written texts, for reasons that need not be discussed here. ${ }^{88}$ The writings that were later called "Gospels" came into existence as parallels to the continuing oral tradition. Once written Gospels were available, they could be read in community gatherings. Reasons as to why any Gospels came to be read in Church gatherings may have included, first, the existing practice of reading apostolic epistles and Prophets and, second, the greater convenience of reading stories from a book rather than telling them from memory.

In a sense, the public reading in the gathering was a practical necessity. Few individual Christians possessed the sacred books and even fewer could afford to pay a scribe to make a copy for them. ${ }^{89}$ Moreover, since the great majority of each congregation's members were illiterate, many Christians could take cognizance of texts only by listening to someone who read them out in the gathering of the community. The composition, circulation, and use of Christian writings in the early Church are evident proof of Christian literacy, but the literature that survives reflects the capacities and viewpoints of Christian literati, who cannot be taken to represent Christians generally.

${ }^{86}$ Harm Hollander, "The Words of Jesus: From Oral Traditions to Written Record in Paul and Q," NovT 42 (2000), 340-344.

${ }^{87}$ See David E. Aune, "Oral Tradition and the Aphorisms of Jesus," and Birger Gerhardsson, "Illuminating the Kingdom: Narrative Meshalim in the Synoptic Gospels," both in Jesus and the Oral Gospel Tradition, ed. Henry Wansbrough (Sheffield: Sheffield Academic Press, 1991), 211-265; 266-309. The classical treatment of the subject is R. Bultmann, Die Geschichte der synoptischen Tradition (Gottingen: Vandenhoeck \& Ruprecht, 1958).

${ }_{88}$ See, e.g., H.N. Roskam, The Purpose of the Gospel of Mark in its Historical and Social Context (Leiden: Brill, 2004), esp. the literature quoted on pp. 223-230.

${ }_{89}$ Claude Cox, "The Reading of the Personal Letter," 85. 
To conclude this section, the rise of the reading of texts in the first century Christian community gatherings can be historically accounted for from four impulses. First of all, reading of texts was a standard element of post-supper symposia in the Graeco-Roman world in general. Second, ever since the days of Paul, apostolic letters were read in Christian gatherings. Once such letters were read, other texts, such as Prophets and Gospels, could be read as well. Third, the Old Testament Prophets began to be read to support Christological teaching. Fourth, Gospels began to be read as a continuation of the story-telling about Jesus. Initially, this story-telling was not based on written texts and served the moral instruction in the Christian gathering; later the stories were written down. From then on, they could be read from written texts such as the "Gospels," and this is what actually happened.

\section{b. Public reading of Scripture in the second century}

In the second century letters of Paul continued to be read in gatherings of Christians. Tertullian testifies to this when he writes that passages from Paul's letters warning against bigamy were being read in assemblies presided over by bishops who themselves committed bigamy.${ }^{90}$ In his De praescriptione haereticorum (about $200 \mathrm{CE}$ ), Tertullian claims, probably with some rhetorical exaggeration, that in cities like Corinth, Philippi, Thessalonica, Ephesus and Rome, the autographed copies of the letters Paul addressed to the Christians there, were still being read in the gatherings of Christians. ${ }^{91}$ This shows at least that Paul's letters were continuing to be read in a number of churches throughout the Mediterranean, although this did not necessarily include the autographs.

Apart from the letters of Paul, other apostolic letters were read in churches in the second century. Eusebius states of the General Epistles of James, Jude, 2 Peter and 2 and 3 John, that "although they were disputed, were nevertheless constantly used publicly in very many churches." 92

90 Tert., Mon. 12.6.

91 Tert., Praescr. 36.1-2.

${ }_{92}$ Euseb., HE 3.31 (my translation). Eusebius enumerates the disputed books at issue in $H E$ 3.25.3. 
In their meetings, Christians read not only letters written by, or in the name, of apostles, but also writings by other Christian authors. Dionysius of Corinth states that on Sundays his church regularly read 1 Clement and a letter of the Roman bishop Soter, both addressed to the Corinthian church. Dionysius says in a letter to Soter: "Today being the Lord's day, we kept it as a holy day and read your [Soter's] epistle, which we shall read frequently for its valuable advice, like the earlier epistle which Clement wrote on your behalf." ${ }^{\text {93 }}$

Another reference to the public reading of an authoritative text in the second century occurs in the sermon 2 Clement: "So then, brothers and sisters, now that we have heard the God of Truth, I am making a request to pay attention to what has been written, so that you may save yourselves and the one who is reading this to you." ${ }^{4}$ With the words "now that we have heard the God of truth" and "pay attention to what has been written" this passage refers to the reading out of a section chosen from apostolic or prophetic writings. ${ }^{95}$ It is not clear which "Scriptural" passages were read, nor can it be ascertained whether the reader of the sermon, 2 Clement itself, was also the reader of the Scriptures.

It may have been with a view to the public reading of letters in the gatherings of their community that the Christians of Philippi asked Polycarp, and subsequently received from him, collected letters of Ignatius. Polycarp sent them these letters with the following note: "We are sending you herewith the letters of Ignatius that he sent to us, along with all the others we had with us, just as you directed us to do. These accompany this letter; you will be able to profit greatly from them." ${ }^{96}$ Polycarp points out that the content of the letters could serve the believers' edification towards the Lord, obviously supposing that Ignatius' letters would be read in the gatherings of the Philippian church.

${ }^{93}$ Euseb., HE 4.23 (tra. G.A. Williamson).

942 Clem. 19.1.

${ }^{95}$ See J.B. Lightfoot, The Apostolic Fathers. Part 1. S. Clement of Rome, vol. 2 (London: MacMillan, 1890), 257, note to line 14; K. Wengst, Didache (Apostellehre), Barnabasbrief, Zweiter Klemensbrief, 216: “... die Mahnung, 'auf das Geschriebene (...) achtzugeben,' kann nicht gut anders verstanden werden denn als Hinweis auf eine vorangegangene Schriftlesung."

${ }^{96}$ Poly., Phil. 13.2. 
There is also evidence for the public reading of writings of another genre: apocalypses. A case in point is the Revelation of John, probably written at the beginning of the second century CE. ${ }^{97}$ The book of Revelation presents itself as a letter addressed to the seven churches in Asia Minor. ${ }^{98}$ The whole epistolary form of Revelation (1:4) as well as Revelation 1:3-8, 11, chapters 2 and 3, and 22:18 reflect the author's supposition that the book would be read in Christian communities, possibly on Sunday, the day already distinguished from other week days by its designation as "the day of the Lord" (1:10). ${ }^{99}$ The first of the seven beatitudes concerns the person who read the text of Revelation in a Christian assembly and his hearers: "Blessed is the one who reads aloud the words of the prophecy, and blessed are those who hear and who keep what is written in it" (Rev. 1:3). The passage just quoted attests that John's Apocalypse was meant for public reading in gatherings of Christian churches. ${ }^{100}$

From Canon Muratori it is clear that later in the second century the Apocalypse of John belonged indeed to the books that were read out regularly in Christian communities. Canon Muratori goes on to say, "some people among us do not want the Apocalypse of Peter to be read in Church." This shows that at least some people accepted the reading of the Apocalypse of Peter in Church. The same applies to the Pastor of Hermas, the public reading of which in Church was accepted by some people, but rejected by Canon Muratori. ${ }^{101}$ This ambiguous situation is confirmed by Eusebius, who states that some authorities in the second century rejected the Pastor of Hermas, whereas others judged it indispensable, especially to those in need of elementary instruction:

${ }^{97}$ H.J. de Jonge, "The Function of Religious Polemics: The Case of the Revelation of John versus the Imperial Cult," in Religious Polemics in Context, eds. T.L. Hettema \& A. van der Kooij (Assen: Van Gorcum, 2004), 276-290, esp. 276-277. This author dates Rev. to 114 C.E. Other authors opt for earlier dates.

${ }_{98}$ J. Leipoldt and S. Morenz, Heilige Schriften (Leipzig: VEB Otto Harrassowitz, 1953), 107.

${ }_{99}$ K. Huber and M. Hasitschka, "Die Offenbarung des Johannes im Kanon der Bibel. Textinterner Geltungsanspruch und Probleme der kanonischen Rezeption," in The Biblical Canons, eds. J.-M. Auwers and H.J. de Jonge (Leuven: University Press \& Peeters, 2003), 611.

100 For an analogy to this phenomenon, see the Syriac Apocalypse of Baruch, written around $100 \mathrm{CE}$, which testifies to the practice of reading apocalyptic writings in the meetings of Jewish congregations: "When therefore you receive this my epistle, read it in your congregations with care" (2 Bar. 86.1-2).

101 Canon Muratori, lines 71-78. 
"Hence-Eusebius says-we know that it has been used before now publicly in a number of churches." 102

Interestingly, the Pastor of Hermas itself refers to the necessity of reading this book, the Pastor, to the Church in Rome:

You will write two little books, sending one to Clement and the other to Grapte. Clement will send his to the foreign cities, for that is his commission. But Grapte will admonish the widows and orphans. And you will read yours in this city, with the presbyters who lead the Church. ${ }^{103}$

This is another indication that an apocalyptic work like the Pastor of Hermas was used for public reading in the Church in the second century.

Apart from letters and apocalypses, the writings read in gatherings of second-century churches could probably also include accounts of Christian martyrdoms. The Martyrdom of Polycarp, usually dated to the middle of the second century CE, states: "When you have learned these things [that is, the contents of the Martyrdom itself], send our letter to the brothers who are further afield, that they may also glorify the Lord." 104 The practice of reading martyrdoms in church is also attested in the Martyrdom of Perpetua and Felicitas. This document is generally thought to have been written not long after 203, the year in which Perpetua died as a Christian martyr somewhere in North Africa, but it seems to mention the reading of martyrdoms in Church gatherings at least as an existing possibility. The author of the literary framework of this work says that "we hold in honour and acknowledge new prophecies and visions such as were promised [namely, in Joel 2:28, as quoted in Acts $2: 17-18] \ldots$ We also deem it imperative to set them forth and to celebrate them by reading them out (lectione celebramus) for the glory of God." 105 This passage betrays that the author knew of the reading of older apocalyptic writings like the Apocalypse of John and the Pastor of Hermas in gatherings of African churches. But the author regards the Martyrdom of Perpetua and Felicitas as a recent apocalypse, which in his opinion deserves no less to be read publicly in churches in Africa. From the passion with which the author pleads for the reading of this particular Martyrdom during Church services

\footnotetext{
102 Euseb., HE 3.3 (my translation).

103 Herm., Vis. 2.8.4 (tra. Bart Ehrman, p. 193).

104 M. Polyc. 20 (tra. Bart Ehrman).

105 M. Perp. 1.5.
} 
it may be gathered that this was not done yet. But this plea also shows that, in principle, the reading of martyrdoms during Church services was considered a good possibility. It should be added that the first official ecclesiastical statement to the effect that martyr acts could be read during Church services is a decision of the Concilium Hipponense of $393 .{ }^{106}$

Clear information about the reading of Gospels during the gatherings of Christians comes, as we have seen above, from Justin Martyr. Justin remarks that in the gathering on Sunday "the memoirs of the apostles or the writings of the prophets are read, as long as time permits." 107 The phrase "as long as time permits" implies that the reading was not of a fixed length.

Precisely what the phrase "as long as time permits" means is not clear. According to one interpretation, it means, "until all the Christians had arrived for the Eucharist." ${ }^{108}$ But this would mean that as soon as all members had arrived, time would no longer allow for the reading to continue. This is a strange supposition, for it implies that the latecomers could do without hearing the reading of the Gospels and Prophets and that listening to the reading of Scriptures was optional. The phrase "as long as time permits" is more likely to have a much more practical meaning. In Justin's church, the reading of Gospels and/or Prophets was followed by a speech, including ethical exhortations and prayers; only then would the supper begin. After the meal, deacons brought food to those members of the church who had not been able to attend the supper, namely, the sick, the disabled and the prisoners. The supper and the distribution of food naturally took some time. In order to allow everybody, including the deacons, to come home not too late at night, the supper had to begin in time. This imposed limitations on the duration of the reading of Gospels and Prophets which preceded the supper.

Canon Muratori notices that some books "cannot be read publicly to the people in the Church" (line 78) and that "some of us are not willing

\footnotetext{
${ }^{106}$ I wish to thank Professor J. den Boeft (Leiden) for bringing this synodal decision to my attention. For the text, see C. Munier (ed.), Concilia Africae A. 345-A. 525 (CCLS 149; Turnhout: Brepols, 1974), 248-253. For the text of Passio Perpetuae, see C.J.M.J. van Beek, Passio Sanctarum Perpetuae et Felicitas, vol. 1 (Nijmegen: Dekker \& van de Vegt, 1936).

107 Just., 1 Apol. 67.3 (tra. L.W. Barnard).

${ }_{108}$ R. Beckwith and W. Stott, The Christian Sunday. A Biblical and Historical Study (Grand Rapids: Baker Book House, 1980), 93.
} 
that (certain writings) be read in Church" (line 72). This implies that other books were actually read publicly in Christian assemblies; Canon Muratori does not say that people objected to these texts being read in Church. This applies, inter alia, to the Gospels of Mark, Matthew, Luke and John. The custom of reading out these Gospels in gatherings seems to have been self-evident to the author of Canon Muratori.

The situation with regard to the reading of the Gospels in the Church, as reflected in Canon Muratori, is confirmed by Irenaeus. This author states: "The entire Scriptures, that is, the Prophets and the Gospels, can be clearly and unambiguously heard by all in the same way, although all do not believe them." ${ }^{109}$ This passage shows that in Irenaeus' church the Gospels were read publicly. It also confirms the information we found in Justin to the effect that Old Testament Prophets and Gospels were the books that were normally read in Church gatherings.

Furthermore, the reading of Gospels in gatherings of Christians is attested by the Acts of Peter, written between 180 and 190 CE. Here Peter is said to have entered the house of Marcellus. When he came into the dining-room (triclinium), "he saw that the gospel was being read. And rolling it up he said, 'Men, who believe in Christ and hope in him, you shall know how the holy Scriptures of our Lord must be explained.... Now I will explain to you that which has been read to you." 110 This account illustrates the established practice of reading from a Gospel in the Christian gathering.

Finally, some testimonies may be mentioned which allude to the reading of Scriptures in gatherings of Christians in the late second century without specifying the type of writing that was read. In his Against Heresies, dating from the years 180-185 CE, Irenaeus argues that true apostolic knowledge is obtained, inter alia, through the reading of Scriptures and the careful explanation in agreement with them. ${ }^{111}$ The reading of Scriptures and their exposition are linked

${ }^{109}$ Iren., Haer. 2.27.2: "Cum itaque universae Scripturae et propheticae, et evangelicae in aperto et sine ambiguitate, et similiter ab omnibus audiri possint etsi non omnes credunt,...."

110 Acta Petri 20 (tra. J.K. Elliott, p. 413).

111 Iren., Haer. 4.33.8: "This is true Gnosis: the teaching of the apostles, and the ancient institution of the church, spread through out the entire world, and the distinctive mark of the body of Christ in accordance with the successions of bishops, to whom the apostles entrusted each local church, and the unfeigned preservation, coming down to us, of the scriptures, with a complete collection allowing for neither addition nor subtraction; a reading without falsification and, in conformity with the 
together here. Since the exposition surely took place in the gathering of the community, one may see here an allusion to the public reading of certain apostolic writings in the meeting of Christians.

Somewhat further on in the same book, in refutation of certain Valentinians who alleged that the prophets uttered some predictions under the inspiration of God, Irenaeus mentions the reading of Scriptures again:

So many are the differences among them on one point, and so many the varied opinions they profess on the same scriptures! When one and the same text has been read, all furrow their brows and shake their head, saying, "This is a very profound word, and not all understand the greatness of the meaning it contains; therefore silence is the greatest thing for the wise." 112

The reading of Scriptures mentioned probably took place during the public service in church where Valentinians heard them read aloud.

In about $200 \mathrm{CE}$, Clement of Alexandria writes about the human soul that tries to approach God by means of several acts of devotion: "A soul giving thanks always for all things to God, by righteous hearing and divine reading, by true investigation, by holy oblation, by blessed prayer; lauding, hymning, blessing, praising, such a soul is never at any time separated from God." 113 Most likely, Clement is describing here rites that took place during the service of the Christian congregation. Reading and hearing of the divine Scriptures were part of those rites.

At about the same time, Tertullian provides a brief description of the Christian assembly in his Apologeticum. Speaking about the reading of Scriptures in the gathering of Christians he writes:

We assemble to read our sacred writings, if any peculiarity of the times makes either forewarning or reminiscence needful. However it be in that respect, with the sacred words we nourish our faith, we animate our hope, we make our confidence more steadfast; and no less by inculcations of God's precepts we confirm good habits. ${ }^{114}$

scriptures, and interpretation that is legitimate, careful, without danger or blasphemy" (tra. Robert M. Grant).

${ }_{112}$ Iren., Haer. 4.35 .4 (tra. Robert M. Grant).

113 Clem. Al., Str. 6.113.3 (ANF).

114 Tert., Apol. 39.3. For another reference in Tertullian to the regular reading of Scriptures in Church, see An. 9.4: "Whether it be in the reading of Scriptures, or in the chanting of Psalms, or in the preaching of sermons, or in the offering up of prayers, in all these religious services matter and opportunity are afforded to her of seeing 
It is interesting to see Tertullian presenting a pastoral purpose of the reading. Through the hearing of Scripture, faith is nurtured, hope is inspired and piety and discipline are strengthened. It can be inferred from Tertullian that at the turn of the second to the third century the reading of Scripture had become an ordinary phenomenon in the assembly of Christians, at least in certain places.

From the material reviewed above it is clear that in the second century the public reading of Scriptures became a customary component of the services of Christian congregations, although practice may have differed from place to place and from time to time. Among the writings used for public reading were apostolic letters, including those of Paul, apocalypses, martyrdoms, Old Testament Prophets and Gospels. The public reading of these texts was meant to edify the audience in various ways. Whereas at Graeco-Roman symposia the reading of texts normally took place after supper, the evidence in Justin and Tertullian suggests that Christians reversed the order and put the reading before the common supper. The easiest explanation of this reversal is that it allowed those who were not yet full members of the congregation, the catechumens, to participate in the service until the common supper began, from which moment on they were excluded, although probably not until the second century. ${ }^{115}$ If the reading of Scripture took place after supper it was difficult to arrange for the catechumens to arrive precisely in time to hear the reading. It was, thus, much more practical to put the reading together with the exposition before the supper.

\section{c. Public reading of Scripture in the third century}

At several places, in the third century, the gatherings of Christians came to be held daily. As a result, the reading of Scripture became a daily practice. Origen, for instance, says that Christians should come to satisfy their thirst for the Word and eat it every day and not only on feast days. ${ }^{116}$ Here we learn for the first time that the Law is read in the Christian assembly. The reading of Scripture was performed both

visions." (tra. Peter Holmes in ANF). "Her" refers to a sister in a Montanist church who had prophetic gifts.

115 Did. 9.5.

116 Or., Hom. Gen. 10.1, 3. 
for the initiated and catechumens, for Origen states that catechumens heard the Law of God every day. ${ }^{117}$

During the third century the second-century custom of reading Pauline and other apostolic epistles, Gospels and Old Testament Prophets continued, but in addition to these writings other books came to be read: the Law, Psalms, and historical books of the Old Testament. From Origen's homilies we can infer that the following books were read in Church services: the Law, Joshua, Judges, 1 Samuel, Psalms, various Old Testament Prophets, Gospels and Pauline Epistles. Hippolytus, too, mentions the reading of Psalms that preceded his sermons. ${ }^{118}$ Eusebius speaks about the public reading of the so-called Catholic or General Epistles:

These things are recorded in regard to James, who is said to be the author of the first of the so-called Catholic Epistles. But it is to be observed that it is disputed; at least, not many of the ancients have mentioned it, as is the case likewise with the epistle that bears the name of Jude, which is also one of the seven so-called Catholic Epistles. Nevertheless we know that these also, with the rest, have been read publicly in very many churches. ${ }^{119}$

Eusebius also states that 1 Clement continued to be read in churches from the time it was sent to the Corinthians down to his own days: "Clement has left us one recognized epistle.... I have evidence that in many churches this epistle was read aloud to the assembled worshippers in early days, as it is in our own." 120

According to Origen, the reading took place in the following way. A reader read successive passages of one book day by day, in the order of the book; each day he continued reading from where he had finished the day before. After the reading, the preacher gave an exposition of what the reader had read. ${ }^{121}$ In one of his expositions, Origen says that "the reading of today is the continuation of yesterday's reading and since we have little time we are going to explain only a small

117 Or., Hom. Jos. 4.

118 Alistair Stewart-Sykes, "Hermas the Prophet and Hippolytus the Preacher: the Roman Homily and Its Social Context," in Preacher and Audience: Studies in Early Christian and Byzantine Homiletics, eds. Mary Cunningham and Pauline Allen (Leiden: Brill, 1998), 61.

119 Euseb., HE 2.23.

120 Euseb., HE 3.16 (tra. G.A. Williamson).

121 Or., Hom. Num. 15.1. 
amount." ${ }^{122}$ The practice of continuous reading may have been the reason why for some people the reading of Scripture became slightly boring. Several sources say that people attending services in Church paid little or no attention to the reading of Scripture. Origen says that "some people do not even patiently wait while the texts are being read in Church. Others do not even know if they are read, but are occupied with mundane stories in the furthest corners of the Lord's house."123 The author of the Syriac Didascalia (third century) complains about the same problem: people fall asleep or gossip away about some other matter and thus they do not listen to what is spoken or read in the fellowship of the assembly on Sunday. ${ }^{124}$

Among the writings used for the reading of Scripture in Church there are two that have not been mentioned so far: the Gospel of Peter and Tatian's Diatessaron. As to the former document, Eusebius relates that Serapion, bishop of Antioch, was confronted with the issue of whether the Gospel of Peter should continue to be read by Christians in Rhossus. At first, Serapion had allowed the reading of this book, but he later forbade it because he found traces of Docetism in it. ${ }^{125}$ Possibly Serapion intended to forbid in particular the public reading of this Gospel in the Church, not its being read in private.

Tatian composed the Diatessaron, a harmony of the four Gospels, about $170 \mathrm{CE} .{ }^{126}$ It was used for public reading in Syrian churches from that time until the fifth century CE when the four separate Gospels replaced it. ${ }^{127}$ Though Tatian was an Encratite, his Gospel harmony was used in the services of many congregations of the regular Church.

The reading of Scripture also took place during Christian festivals and other types of gatherings such as baptismal rites and the commemoration of the deaths of martyrs. In certain places, such as Syria, a vigil was held before Easter from Saturday evening to dawn on

122 Or., Hom. Lev. 7.1.

123 Or., Hom. Ex. 12.2 .

${ }^{124}$ Did. ap. 3.6.

${ }^{125}$ Euseb., HE 6.12. It is not absolutely clear from this passage that Serapion is opposing the reading of the Gospel of Peter publicly in Church. He may have intended to protest against private reading of the book.

${ }_{126}$ William L. Petersen, Tatian's Diatessaron (Leiden: Brill, 1994), 426-427.

127 Theodoret of Cyrrhus, Treatise on Heresies 1.20; W.L. Petersen, Tatian's Diatessaron, 41-43; P.R. Ackroyd and C.F. Evans (eds.), The Cambridge History of the Bible, vol. 1, From the Beginnings to Jerome (Cambridge: Cambridge University Press, 1970), 567. 
Sunday. The order of this Easter vigil included readings from Scripture and a homily. ${ }^{128}$ The Didascalia says that during the Easter vigil the Scriptures and the Psalms were read. ${ }^{129}$ The Apostolic Tradition gives an account of the reading to the catechumens during the Easter vigil in the night preceding baptism on Sunday morning. ${ }^{130}$ The author of the Didascalia writes that Christians, in accordance with the Gospel and the power of the Holy Spirit, should gather together in the cemeteries and read the Holy Scriptures and perform their ministry and supplications to God. ${ }^{131}$ Thus, during the third century the Scriptures were read on more occasions than just the Sunday gathering.

\section{THE OFFICE OF READER}

The office of "reader" or "lector" has arisen within the Church at the end of the second century: Tertullian in North Africa is the first to attest the existence of the function of reader. ${ }^{132}$ The office surely originated earlier than this testimony.

Before the rise of the office of reader, ordinary members of the community who were capable of reading must have performed the reading of Scripture in Christian gatherings. Testimony of this may be found in Revelation 1:3 which pronounces a blessing upon "the one who reads." Obviously, this reader has no official capacity, for here the par-

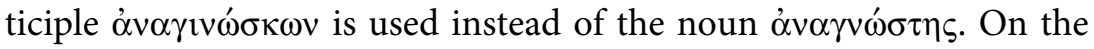
other hand, in 1 Timothy 4:13, the responsibility for reading is laid upon the community leader, that is, "Timothy." Both texts come from Asia Minor and from approximately the same time. At first sight, these writings seem to differ as to the question of who performed the reading in the gathering. But this is probably due only to the character of 1 Timothy, in which "Paul" charges "Timothy" with many sorts of pastoral and liturgical tasks. 1 Timothy does not exclude that the reading was undertaken by people other than the head of the community.

\footnotetext{
${ }_{128}$ Stuart Hall, Doctrine and Practice in the Early Church (Philadelphia: Fortress Press, 1973), 19.

${ }_{129}$ Did. ap. 5.19.

130 Trad. ap. 20.

131 Did. ap. 6.22.

132 Tert., Praescr. 41.8.
} 
As to "the reader" who "must understand" in Mark 13:14 (Mt. 24:15), there is little reason to assume that this is a person who read the Gospel in Church. In fact, what has to be understood here should be understood, not by the lector alone, but by anybody who reads about "the desolating sacrilege" in Daniel 11:31: in light of Daniel 11:31 one should understand that the presence of the Romans in the Jerusalem temple is a sign of the end. Mark 13:14 does not refer to a "liturgical" reader, therefore; it refers to anybody who reads about the "desolating sacrilege" in Daniel 11:31.

Because of the difficult legibility of ancient handwriting, even of book scripts, reading in antiquity was a hard task. ${ }^{133}$ As a result, people who could read a book at sight were admired. ${ }^{134}$ For the same reason, public reading in the ancient world called for some technical accomplishment. It is understandable, therefore, that churches gradually preferred not to rely on the unpredictable presence of someone who was able to read in public, but appointed some educated and trained person in the congregation to serve as official reader. The sociocultural counterpart and analogy of this reader was the reader acting at Graeco-Roman banquets. ${ }^{135}$

Justin's account of the Sunday gathering mentions "the moment when the person who reads [namely a passage from a Gospel or a Prophet] stops reading." ${ }^{36}$ But Justin does not use a noun designating an office and it cannot be deduced from this passage that he already knew the office of lector. Tertullian, however, is acquainted with the reader as an official of the Church. ${ }^{137}$

From the third century onwards the reader appears as an official functionary who, at various places, assists bishops and other clergy in conducting the service of Christian congregations. The ceremony of the appointment of a reader is attested in the Apostolic Tradition: "A reader is installed as the bishop hands him a book. He has no laying on of hands." ${ }^{38}$ Origen states that the reader became a member of the

133 P. Achtemeier, "Omne Verbum Sonat: The New Testament and the Oral Environment of Late Western Antiquity," 17.

134 Petr., Satyr. 75.

135 See, e.g., Nep., Att. 13.3; 14.1; Plin., Ep. 9.17. The phenomenon of the professional reader has been discussed in the beginning of the present chapter.

136 Just., 1 Apol. 67.4.

137 Tert., Praescr. 41.8.

138 Trad. ap. 11 (tra. A. Stewart-Sykes). Cf. Euseb., HE 6.43.11 (Rome, 251 CE). 
clergy in Caesarea. ${ }^{139}$ On the other hand, when Origen enumerates clergy, he does not always mention the reader. ${ }^{140}$

The appointment of lectores is also attested in Carthage. ${ }^{141}$ Cyprian writes that he ordained a certain Saturus as a reader, a man who had been used twice before to read the Scriptures on Easter day. He also speaks about a young Christian, Aurelius, who became twice a confessor and, as a result, merited a higher rank in the clerical order. However, in view of Aurelius' young age Cyprian thought it well for him to begin in the office of reader and use his voice for declaiming the divine Scriptures. ${ }^{142}$ Cyprian regarded the function of reader in the Church as a noble office:

This man [Celerinus] comes to us, my dearly beloved brothers, thus highly favoured by the Lord; he comes illustrious with the testimonyand indeed wonderment - of his very persecutor. There is no place more proper for him to be stationed than on the pulpit, that is to say on the tribunal of the church. In this way, thanks to his elevated position, he may be readily seen by the whole congregation in a manner befitting the brilliance of his honour and there he may read to them those commandments and the Gospel of the Lord which he follows with such fortitude and faithfulness. My hope is that the voice which has confessed the Lord may be daily heard proclaiming the words which the Lord has spoken. There may be, to be sure, higher grades to which one can rise in the Church, but the task by which the confessor can render most profit to his brethren is by reading with his own lips the Gospel. Those who hear may thereby imitate the faith of the reader. ${ }^{143}$

According to Cyprian, the church in Carthage did well to ordain confessors in the rank of reader. His idea was that when those who heard the Scriptures from the lips of a confessor, they would be inspired to follow the example of the confessor's faith. In times of persecution the leadership naturally wanted to encourage all members to stand firm and become good confessors. One of the means to pursue this goal was to assign the office of reader to confessors who had proven themselves in persecution and whose faith and perseverance could serve as examples for those who heard them read the Scriptures.

139 Or., Hom. Num. 15.1.

140 Or., Hom. Jer. 14.4.9; Orat. 28.4.

141 Cypr., Ep. 29.1 (Carthage, ca. 250 CE).

142 Cypr., Ep. 38.2.

143 Cypr., Ep. 39.4.1-2 (tra. G.W. Clarke). 
In the Didascalia it is not a reader, but the bishop himself who performs the reading from the Scriptures during the Church gathering. He does so in a sitting position. ${ }^{144}$ By contrast, the so-called Apostolic Church Order, probably composed in Egypt at the end of the third century, allows for the possibility of a bishop to be illiterate, but presupposes the presence of a reader in that case. The reader should be tested before being appointed. He should dispose of a great number of moral and other qualities, among which is his habit of arriving early in church on Sunday. ${ }^{145}$ In the middle of the third century, the Christian Latin poet Commodianus composed a poem in which he gives instructions concerning the way the readers in the Christian community should live. They should devote themselves to study and give an example of a virtuous life to the world. They should give honour to the elders in the church, and imitate Christ their master, since they are the lamps of Christ. ${ }^{146}$ From Cyprian and Commodianus it becomes clear that in the third century the office of reader in the Christian assembly became important owing to the fact that it was mainly through the reader that the rest of the assembly could hear and come to know the Scriptures.

\section{Conclusions}

In the twentieth century, scholars who studied the Christian Sunday evening gathering used to trace its pattern back to a supposed Jewish synagogue service. As a result, they were forced to assume that the reading of Scripture as practised in the weekly gathering of Christians was the continuation of the reading of the Law and the Prophets in synagogal services. The present chapter has shown that the reading of Scripture in the Christian gathering is more likely to have its origins in the custom of reading literary works and other writings during the symposium part of banquets in the Graeco-Roman world. Such banquets were held by non-Jews and Jews alike.

In the first century CE the reading of texts in the Christian gathering first had the form and function of the reading of apostolic epistles as "letters received." Subsequently, Christians began to read the same

144 Did. ap. 2.58.

145 Can. apost. 16; 19.

146 Comm., Instr. 26. 
letters repeatedly; several letters were also read in other congregations than the ones to which they had been addressed originally. With time, Christians also began to read portions from the Old Testament Prophets in their assemblies. Once one or more Gospels had been written, these, too, came to be read in gatherings of Christian communities, in some places perhaps from the end of the first century onwards. During the second century various kinds of Christian writings were read publicly in Christian churches: letters of apostles and other Christian authors, apocalypses, Gospels and Prophets. It seems that the public reading of the Law in Christian gatherings did not begin until the third century CE. Finally, this chapter entered into the rise of the office of reader in Christian congregations. Readers were used at banquets all over the Graeco-Roman world. In Christian congregations texts were read at first by members who were capable of doing so. By the end of the second century, the function of reader became an office in the Church. It soon came to be the first or lowest rank in the career path of ecclesiastical office holders. 